\title{
THYROID
}

\section{Can preoperative serum thyroglobulin levels predict the risk of malignancy? Results from prospective analysis of biochemical predictors of malignancy in thyroid nodules}

\author{
Valore predittivo dei livelli sierici di tiroeglobulina nei tumori maligni della tiroide. \\ Risultati di un'analisi prospettica in pazienti con noduli tiroidei

\begin{abstract}
Narendra Hulikal', Azhagamuthu RE¹, Manilal Banoth¹, Amith Kumar Chowhan², Mutheswaraiah Yutla ${ }^{3}$, Alok Sachan ${ }^{4}$
${ }^{1}$ Department of Surgical Oncology, ${ }^{2}$ Department of Pathology, ${ }^{3}$ Department of General Surgery, ${ }^{4}$ Department of Endocrinology, Sri
\end{abstract} \\ Venkateswara Institute of Medical Sciences, Tirupati, Chittoor district, Andhra Pradesh, India
}

\begin{abstract}
SUMMARY
Although thyroid nodule is a common presentation, malignancy is rare. The present study investigated biochemical predictors of malignancy in enlarged thyroid. This is a prospective study of all willing patients 18 to 70 years presenting with a complaint of thyroid swelling and who underwent definitive surgery over a period of 19 months. All subjects were initially evaluated with detailed history, physical examination, ultrasonography of neck and fine needle aspiration cytology (FNAC). Preoperative estimation of serum thyroid stimulating hormone (TSH), thyroglobulin (Tg) and anti-thyroglobulin (anti $\mathrm{Tg}$ ) antibody was obtained. The treatment plan was based on FNAC results and included hemi- or total thyroidectomy. During the study period, 110 patients underwent thyroidectomy, and met the selection criteria, of which 47 patients had malignancy on final histopathology. The majority were females, 30 to 60 years old. Median serum $\mathrm{Tg}$, TSH and anti Tg levels in the benign group were, respectively $29 \mathrm{ng} / \mathrm{ml}, 1,6 \mathrm{mIU} / \mathrm{L}$ and 1,1 $\mathrm{IU} / \mathrm{ml}$, whereas in malignant nodules they were $162 \mathrm{ng} / \mathrm{ml} .1,7 \mathrm{mIU} / \mathrm{L}$ and $0,9 \mathrm{IU} / \mathrm{ml}$. On receiver operating characteristic curve analysis, a Tg cut off value of $53 \mathrm{ng} / \mathrm{ml}$ predicted malignancy risk with a sensitivity and specificity of $72 \%$ and $73 \%$, respectively $(p<0.001)$. Our study showed the utility of preoperative $\mathrm{Tg}$ in predicting risk of malignancy. Its role should be further explored especially in the backdrop of indeterminate cytology through a larger study.
\end{abstract}

KEY WORDS: head and neck cancer, thyroid neoplasms, thyroglobulin, thyrotropin, thyroidectomy

\section{RIASSUNTO}

Nonostante i noduli tiroidei siano frequenti, i tumori maligni della tiroide sono rari. Questo studio indaga il valore predittivo di malignità di markers biochimici plasmatici in caso di noduli tiroidei. Sono stati analizzati pazienti di età compresa fra i 18 e 70 anni, affetti da struma tiroideo e sottoposti a chirurgia in un periodo di 19 mesi. Tutti i pazienti sono stati sottoposti ad anamnesi, visita clinica, ecografia del collo e agoaspirato tiroideo. Sono stati effettuati prelievi per il dosaggio del TSH, tireoglobulina ed anticorpi antitireoglobulina. La chirurgia ha incluso l'emitiroidectomia o la tiroidectomia totale sulla base dello FNAC. 110 pazienti sono stati sottoposti a chirurgia di cui 47 con diagnosi istopatologica finale di malignità, principalmente di sesso femminile, di età compresa fra i 30 e 60 anni. I livelli sierologici medi di Tg, TSH ed anticorpi antiTG nei pazienti con noduli benigni sono stati ripettivamente $29 \mathrm{ng} / \mathrm{ml}, 1,6 \mathrm{mIU} / \mathrm{L}$ e 1,1 IU/ml, mentre nei noduli maligni erano $162 \mathrm{ng} / \mathrm{ml}$. 1,7 $\mathrm{mIU} / \mathrm{L}$ e $0,9 \mathrm{IU} / \mathrm{ml}$. Il valore cut off della tireoglobulina predittivo di malignità è stato $53 \mathrm{ng} / \mathrm{ml}$ con una sensibilità e specificità del $72 \%$ and $73 \%,(p<0,001)$. Il nostro studio ha mostrato l'utilità dei valori di tireoglobulina come marker predittivo di malignità. Tali risultati vanno meglio approfonditi, in gruppi più ampi e specialmente in quei pazienti il cui FNAC risulta non diagnostico.

PAROLE CHIAVE: tumori testa e collo, neoplasie tiroidee, tireoglobulina, tireotropina, tiroidectomia
Received: May 2, 2019

Accepted: August 3, 2019

\section{Correspondence}

Narendra Hulikal

Department of Surgical Oncology, Sri Venkateswara Institute of Medical Sciences, Tirupati, Chittoor district, Andhra Pradesh, India-517507

Tel. +91 7382629699

E-mail: drnarendrah@yahoo.co.in

Funding

None.

Conflict of interest

The Authors declare no conflict of interest.

How to cite this article: Hulikal N, RE A, Banoth $\mathrm{M}$, et al. Can preoperative serum thyroglobulin levels predict the risk of malignancy? Results from prospective analysis of biochemical predictors of malignancy in thyroid nodules. Acta Otorhinolaryngol Ital 2020;40:33-37. https:// doi.org/10.14639/0392-100X-N0276

() Società Italiana di Otorinolaringoiatria e Chirurgia Cervico-Facciale

\section{(c) (1) $(9)$}

This is an open access article distributed in accordance with the CC-BY-NC-ND (Creative Commons Attribution-NonCommercial-NoDerivatives 4.0 International) license. The article can be used by giving appropriate credit and mentioning the license, but only for non-commercial purposes and only in the original version. For further information: https:// creativecommons.org/licenses/by-nc-nd/4.0/deed.en 


\section{Introduction}

Thyroid nodule is a common presentation and requires a structured diagnostic approach to ascertain the risk of malignancy and determine appropriate management. With a 5-10\% lifetime risk of developing a palpable thyroid nodule, they can be detected by palpation in 10\% of women and $2 \%$ of men ${ }^{1}$. However, with high resolution ultrasound they can be detected in a $19-68 \%$ of the randomly selected population ${ }^{2}$. The risk of thyroid malignancy in a nodule depends on various factors attributable to the patient's history as well as clinical, sonological and metabolic features of the nodule, and is roughly estimated to be $3-15 \%{ }^{3,4}$. Their accuracy in predicting the presence of malignancy is debatable. The clinical significance rests mainly on the need to exclude thyroid cancer, especially in so called incidentalomas or nonpalpable lesions. Most guidelines recommend evaluation of only nodules greater than $1 \mathrm{~cm}$ owing to the greater potential to be clinically significant cancers. Occasionally, there may be nodules smaller than $1 \mathrm{~cm}$ that require evaluation because of suspicious sonological features or metabolic activity, associated lymphadenopathy, history of head and neck irradiation, or family history of thyroid cancer ${ }^{4}$.

Though patients with multiple nodules have the same risk of malignancy as those with a single nodule ${ }^{5}$, one large study found that a solitary nodule had a higher likelihood of malignancy than did a non-solitary nodule although the risk of malignancy per patient was the same and independent of the number of nodules ${ }^{6}$. Furthermore, the nodular gland may be secreting hormones normally, subnormally or supranormally. At present, any suspicious nodule on sonography is subjected to guided fine needle aspiration cytology (FNAC), the result of which decides the need for surgery. In about 15 to $30 \%$ of patients, the aspirate can be indeterminate $^{7}$, which is associated with more than a $20 \%$ risk of malignancy. Hence, it is reasonable to conclude that a significant number of patients with nodules need surgery to exclude malignancy with the antecedent risk of recurrent laryngeal injury and permanent hypoparathyroidism.

While there is exhaustive literature on clinical and sonological cancer predicting risk factors in a nodule, recent area of research has been on biomarkers such as serum thyroid stimulating hormone (TSH), thyroglobulin ( $\mathrm{Tg}$ ) and antithyroglobulin (anti-Tg) antibody. Thus, the present study was planned to evaluate the potential role of these biochemical factors as preoperative indicators of thyroid malignancy.

\section{Materials and methods}

A prospective study of all eligible, willing patients presenting with thyroid swelling from May 2015 to
December 2016 was planned and institutional ethical committee approval was given for the protocol. To be eligible, patients were to be 18 to 70 years old and willing to participate in the study. Patients with recurrent disease, diffuse thyroid enlargement, clinical hypothyroidism, thyrotoxicosis, proven extrathyroidal disease, poorly differentiated cytology, lymphoma or metastasis from elsewhere were excluded.

All study subjects were evaluated clinically with detailed history, physical examination, neck sonography, thyroid profile consisting of serum TSH, triiodothyronine and thyroxine, $\mathrm{Tg}$, anti- $\mathrm{Tg}$ antibody and fine needle aspiration cytology. The size of the nodule as measured using a 10 $\mathrm{mHz}$ high frequency ultrasonographic probe. Based on the FNAC report, a treatment plan was made. A decision of hemi- or total thyroidectomy was made primarily on the FNAC report and secondarily on the presenting clinical scenario. The nodules where the preoperative FNAC was inconclusive (either suspicious or indeterminate), the hemithyroidectomy specimen were sent for frozen section analysis. Data on age and sex of subjects, voice change, number and size of the nodule/largest nodule, FNAC, frozen section and final histopathology findings along with the preoperative biomarker information such as serum levels of TSH, Tg and anti-Tg antibody were collected. Any further treatment and follow-up were done as per our standard practice.

Lesions were grouped as benign or malignant based on final histopathology, and based on this information, receiver operating characteristic curves (ROC) were plotted for serum Tg, Anti-Tg antibody and TSH levels.

\section{Laboratory methods}

Serum thyroglobulin, anti-thyroglobulin and thyroid stimulating hormone were determined using chemiluminescence immunoassay (CLIA), and processed using a Beckman Access-2 analyser (Beckman Coulter Access, GMI Inc, Germany).

\section{Results}

During the study period, 110 patients presented with thyroid nodules, of which 18 were excluded. The majority of patients were women ( 72 of 92) and were 30 to 60 years old (51 of 92, Tab. I). On final histopathology, 47 patients harboured malignancy (Tab. I). The sensitivity, specificity, positive predictive value and negative predictive value for FNAC and frozen sections were $77 \%, 71 \%, 73 \%, 74 \%$ and $70 \%, 100 \%, 100 \%$ and $68 \%$, respectively. The accuracy of FNAC was $71 \%$ and for frozen section was $73 \%$. 
Table I. Clinicopathological profile of the study subjects.

\begin{tabular}{lccc} 
Characteristic & Benign & Malignant & P value \\
Age (years) & & & \\
45 or less & 23 & 23 & 0.83 \\
$>45$ & 22 & 24 & \\
Sex & & & \\
Female & 38 & 34 & 0.13 \\
Male & 07 & 13 & \\
Size of nodule & & & \\
2 cm or less & 18 & 23 & 0.38 \\
$>2$ cm & 27 & 24 & \\
Biomarkers (mean value) & & & \\
TSH (IU/L) & 1.94 & 2.16 & \\
Tg (ng/ml) & 72.55 & 215.05 & \\
Anti-Tg antibody (IU/ml) & 2.84 & 6.99 & \\
FNAC & & & \\
Benign $(n=34)$ & 27 & 07 & \\
Borderline ( $n=9)$ & 04 & 05 & \\
Suspicious ( $n=24)$ & 08 & 16 & \\
Malignant $(n=25)$ & 05 & 20 & \\
Frozen section & & & \\
Benign $(n=16)$ & 00 & 12 & \\
Malignant $(n=12)$ & & & \\
\hline
\end{tabular}

\section{Serum biomarkers}

Serum thyroglobulin ( $\mathbf{T g})$ : the levels of $\mathrm{Tg}$ varied from 0.1 to $500 \mathrm{ng} / \mathrm{ml}$ with a median of $29 \mathrm{ng} / \mathrm{ml}$ in patients with benign nodules compared to 0.3 to $816 \mathrm{ng} / \mathrm{ml}$ with a median of $162 \mathrm{ng} / \mathrm{ml}$ among malignant nodules (Fig. 1). A ROC curve was plotted as shown in Figure 2. Using ROC analysis, we obtained a cut-off of $53 \mathrm{ng} / \mathrm{ml}$, with a sensitivity of $72 \%$, specificity of $73 \%$ and a $p$ value of $<0.001$ (Fishers exact test, Fig. 2, Tab. II).

Serum anti-thyroglobulin (anti-Tg) antibody: in the present study, mean serum anti-Tg antibody levels in benign and malignant nodules were 2.25 and $7.27 \mathrm{IU} /$ ml, respectively, (Fig. 3) with median values of 1.1 and

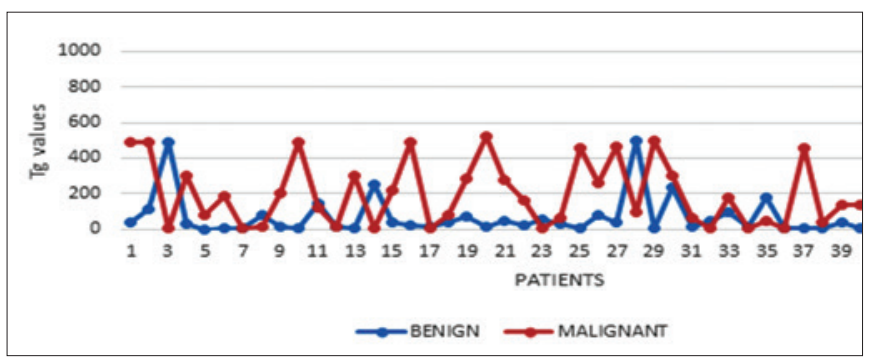

Figure 1. Distribution of serum Tg values in benign and malignant groups.

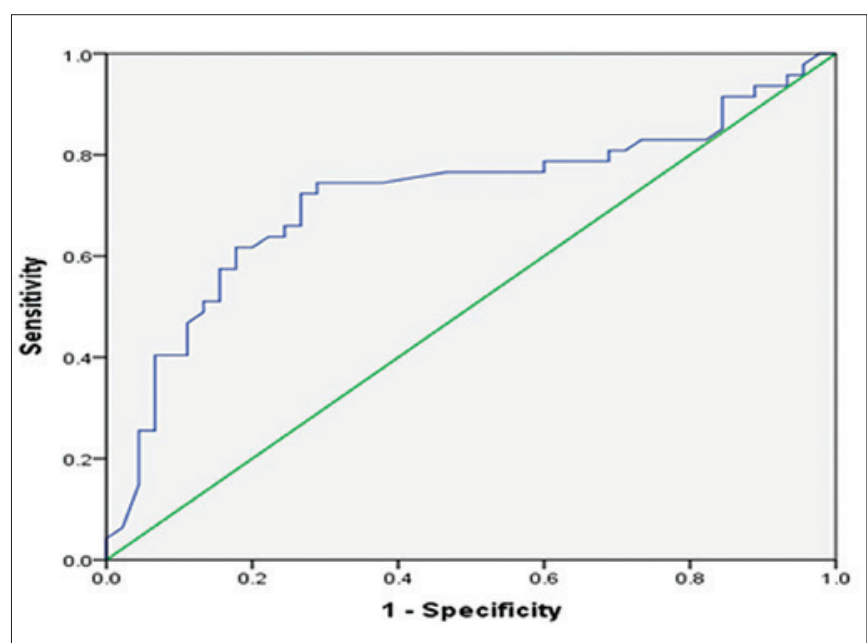

Figure 2. ROC Curve of serum $\mathrm{Tg}$ values.

Table II. Analysis of ROC curve and Chi-square test of Tg.

\begin{tabular}{lc}
\hline Area under the curve & 0.716 \\
ROC P value & 0.001 \\
Sensitivity & $72.3 \%$ \\
Specificity & $73.3 \%$ \\
Cut-off & $53 \mathrm{ng} / \mathrm{ml}$ \\
p value (Fischer exact test) & $<0.001$ \\
\hline
\end{tabular}

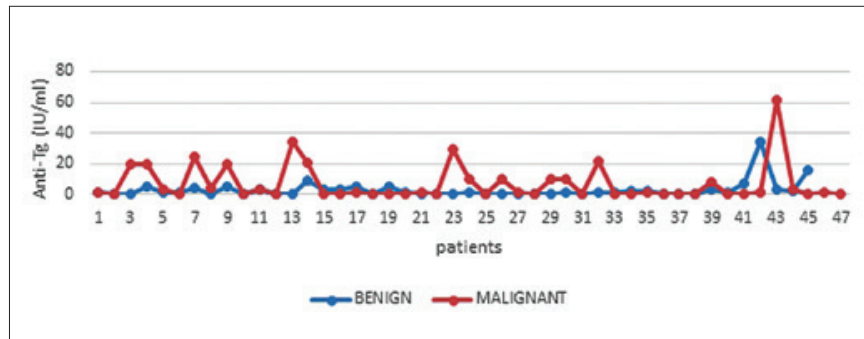

Figure 3. Distribution of serum anti-Tg antibody levels in benign and malignant groups.

$0.9 \mathrm{IU} / \mathrm{ml}$. On ROC analysis, there was no statistically significant association of anti-Tg antibody levels with risk of malignancy $(\mathrm{P}$ value $=0.34$, Fischer exact test $)$.

Serum thyroid stimulating hormone (TSH): mean TSH in benign and malignant nodules were 1.94 and $2.15 \mathrm{mIU} / \mathrm{L}$ with a median of $1.6 \mathrm{mIU} / \mathrm{L}$ and $1.7 \mathrm{mIU} / \mathrm{L}$, respectively (Fig. 4). On ROC analysis, there was no significant correlation with risk of malignancy $(\mathrm{P}$ value $=0.54$, Fisher exact test). 


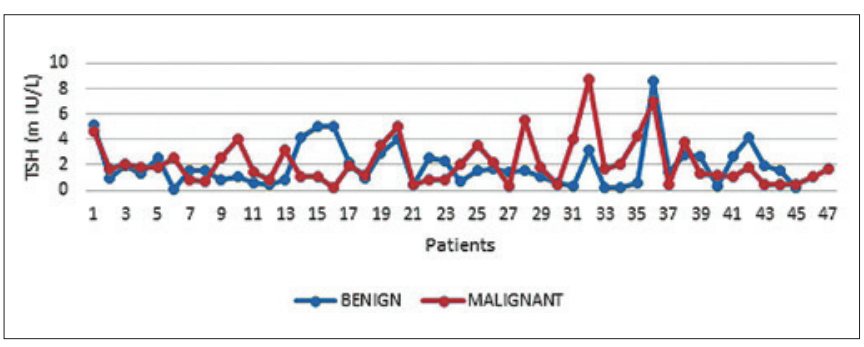

Figure 4. Distribution of serum TSH among benign and malignant nodules.

\section{Discussion}

Even if thyroid nodule is a common presentation, cancer is rare, representing $1 \%$ of all cancers. Accordingly, it requires a structured diagnostic approach to ascertain the risk of malignancy and determine appropriate management. Increasing incidence of thyroid nodules partly owing to incidental detection mandates us to improve our understanding on the risk factors and biomarkers that might help in guiding their management. While FNAC is a cost-effective, simple, outpatient procedure, its accuracy depends on the experience of the cytopathologist. The reported sensitivity and specificity of FNAC varies from 65 to $98 \%$ and $73-100 \%$ respectively ${ }^{7}$. The major reason for such a wide variation among studies are differences in categorisation of follicular neoplasms, suspicious of malignancy and atypical cell of unknown significance/ follicular lesion of unknown significance. Common factors for false negatives are inadequate sampling due to calcified nodules, unguided FNAC, difference in inclusion of Bethesda categories under benign and malignant lesions and interobserver variability among reporting cytopathologists. While guided FNAC was not strictly mandated in our study, its sensitivity and specificity in diagnosing malignant nodules are comparable to other studies.

Currently, serum Tg is used in the follow-up of patients with well differentiated thyroid cancer (WDTC) to monitor disease recurrence. The diagnostic value of preoperative serum Tg is still an area of intense debate. Sands et al. in a retrospective study on 861 patients, of whom nearly $35 \%$ had indeterminate cytology, $81 \%$ with both indeterminate cytology and preoperative $\mathrm{Tg} \geq 75 \mathrm{ng} / \mathrm{ml}$ had welldifferentiated cancer on final pathology compared to $58 \%$ with indeterminate cytology alone $(\mathrm{p}=0.014, \mathrm{RR}=1.4)$. They concluded that a combination of indeterminate cytology and preoperative $\mathrm{Tg} \geq 75 \mathrm{ng} / \mathrm{ml}$ increased diagnostic efficacy compared to indeterminate cytology alone ${ }^{8}$. In another retrospective study of 164 patients with indeterminate cytology undergoing surgery, Lee et al. reported that a cut off $\mathrm{Tg}$ more than $70 \mathrm{ng} / \mathrm{ml}$ predicted cancer risk in nodules more than $1.7 \mathrm{~cm}$ with a sensitivity and specificity of $67.7 \%$ and $60.7 \%$, respectively. When the size of the nodule was ignored, a serum $\mathrm{Tg}$ value of more than $100 \mathrm{ng} / \mathrm{ml}$ predicted increased risk ${ }^{9}$. Another study of 97 follicular neoplasm by Lee et al. reported that preoperative serum $\mathrm{Tg}$ levels of $75 \mathrm{ng} / \mathrm{ml}$ or more and presence of calcification on ultrasonography predicted malignant risk ${ }^{10}$. Similarly, in our prospective study of 92 patients (of which 33 had indeterminate cytology), $76 \%$ of patients (13 of 17) with both indeterminate cytology and preoperative $\mathrm{Tg}>53 \mathrm{ng} / \mathrm{ml}$ had well differentiated cancer on final histopathology compared to 60\% (20 of 33) of patients with indeterminate cytology alone. We also conclude that combination of indeterminate cytology and preoperative $\mathrm{Tg}>53 \mathrm{ng} / \mathrm{ml}$ increased diagnostic efficacy compared to indeterminate cytology alone. While indeterminate cytology was only $35 \%$ of our study population, a larger prospective study in this subset would answer whether serum Tg levels could predict risk of malignancy to guide surgery. Some authors have reported higher levels of preoperative serum $\mathrm{Tg}$ levels for diagnosing risk of malignancy ${ }^{11-14}$.

It has been reported that the prevalence of WDTC is higher in patients with elevated anti-Tg antibody levels compared with the general population. The association between autoimmune thyroiditis and thyroid cancer is still not clear. A retrospective study of 1638 subjects by Kim et al. using multivariate regression analysis concluded that elevated anti- $\mathrm{Tg}$ antibody (odds ratio $=1.61 ; 95 \% \mathrm{CI}: 1.21-2.23$ ) and elevated serum TSH (odds ratio $=1.72 ; 95 \%$ CI: 1.12 2.63) were significantly associated with malignancy ${ }^{15}$. Another retrospective study of 854 patients by Vasileiadis et al. also concluded that tumour size $>10 \mathrm{~mm}(p<0.001)$ and preoperative anti-Tg antibody levels $(p=0.003)$ were independent risk factors of malignancy ${ }^{16}$. A study on 108 patients reported that preoperative serum TSH level may be useful in predicting cancer in thyroid nodules. In that study, mean serum TSH in malignant vs benign nodules were 1.94 vs $1.16 \mathrm{mIU} / \mathrm{L}(p<0.005)^{17}$. Similarly, in a study of 63 patients, mean serum TSH in malignant and benign groups were $5.5 \mathrm{vs} 1.4 \mathrm{mIU} / \mathrm{L}(p=0.001)^{18}$. In the present study, we could not find no association of malignancy with either preoperative serum anti-Tg antibody or serum TSH levels in contrast with other studies ${ }^{19-25}$.

\section{Conclusions}

Preoperative serum $\mathrm{Tg}$ may be a useful biomarker in differentiating benign from malignant thyroid nodules when a cut-off more than $53 \mathrm{ng} / \mathrm{ml}$ is used. Hence, we feel that preoperative $\mathrm{Tg}$ levels could be incorporated in counselling patients for surgery as well as the need for surgery. Its role in the background of indeterminate cytology needs further 
exploration through a large prospective study. We could not demonstrate any association between preoperative levels of serum anti-Tg or TSH with risk of malignancy.

\section{References}

1 Tunbridge WM, Evered DC, Hall R, et al. The spectrum of thyroid disease in a community: the Whickham survey. Clin Endocrinol (Oxf) 1977;7:481-93. https://doi.org/10.1111/j.1365-2265.1977.tb01340.x

2 Guth S, Theune U, Aberle J, et al. Very high prevalence of thyroid nodules detected by high frequency $(13 \mathrm{MHz})$ ultrasound examination. Eur J Clin Invest 2009;39:699-706. https://doi.org/10.1111/j.13652362.2009.02162.x

3 Marqusee E, Benson CB, Frates MC, et al. Usefulness of ultrasonography in the management of nodular thyroid disease. Ann Intern Med 2000;133:696-700. https://doi.org/10.7326/0003-4819133-9-200011070-00011

4 Hagag P, Strauss S, Weiss M. Role of ultrasound guided fine-needle aspiration biopsy in evaluation of nonpalpable thyroid nodules. Thyroid 1998;8:989-95. https://doi.org/10.1089/thy.1998.8.989

5 Papini E, Guglielmi R, Bianchini A, et al. Risk of malignancy in nonpalpable thyroid nodules: predictive value of ultrasound and colour doppler features. J Clin Endocrinol Metab 2002;87:1941-6. https://doi.org/10.1210/jcem.87.5.8504

6 Frates MC, Benson CB, Doubilet PM, et al. Prevalence and distribution of carcinoma in patients with solitary and multiple thyroid nodules on sonography. J Clin Endocrinol Metab 2006;91:3411-7. https://doi. org/10.1210/jc.2006-0690

7 Pinchera A, Aghini-Lombardi F, Antonangeli L, et al. Multinodular goitre. Epidemiology and prevention. Ann Ital Chir 1996;67:317-25.

8 Sands NB, Karls S, Rivera J, et al. Preoperative serum thyroglobulin as an adjunct to fine-needle aspiration in predicting well-differentiated thyroid cancer. J Otolaryngol Head Neck Surg 2010;39:669-73.

9 Lee EK, Chung KW, Min HS, et al. Preoperative serum thyroglobulin as a useful predictive marker to differentiate follicular thyroid cancer from benign nodules in indeterminate nodules. J Korean Med Sci 2012;27:1014-8. https://doi.org/10.3346/jkms.2012.27.9.1014

10 Lee SH, Baek JS, Lee JY, et al. Predictive factors of malignancy in thyroid nodules with a cytological diagnosis of follicular neoplasm. Endocr Pathol 2013;24:177-83. https://doi.org/10.1007/s12022-013-9263-x

11 Petric R, Perhavec A, Gazic B, et al. Preoperative serum thyroglobulin concentration is an independent predictive factor of malignancy in follicular neoplasms of the thyroid gland. J Surg Oncol 2012;105: 351-6. https://doi.org/10.1002/jso.22030

12 Besic N, Sesek M, Peric B, et al. Predictive factors of carcinoma in 327 patients with follicular neoplasm of the thyroid. Med Sci Monit 2008;14:CR459-67.
13 Sugino K, Ito K, Mimura T, et al. Hürthle cell tumor of thyroid: analysis of 188 cases. World J Surg 2001;25:1160-3. https://doi. org/10.1007/bf03215865

14 Okamoto T, Kanbe M, Iihara M, et al. Measuring serum thyroglobulin in patients with follicular thyroid nodule: its diagnostic implications. Endocor J 1997;44:187-93. https://doi.org/10.1507/endocrj.44.187

15 Kim ES, Lim DJ, Baek KH, et al. Thyroglobulin antibody is associated with increased cancer risk in thyroid nodules. Thyroid 2010;20:88591. https://doi.org/10.1089/thy.2009.0384

16 Vasileiadis I, Boutzios G, Charitoudis G, et al. Thyroglobulin antibodies could be a potential predictive marker for papillary thyroid carcinoma. Ann Surg Oncol 2014;21:2725-32. https://doi. org/10.1245/s10434-014-3593-X

17 Zeng Q, Liu J, Zhu J, et al. Association between preoperative serum thyroid-stimulating hormone level and non-functioning malignant nodule thyroid disease. Lin Chung Er Bi Yan HouTou Jing WaiKeZaZhi. 2014;28:1931-3.

18 Okayasu I, Fujiwara M, Hara Y, et al. Association of chronic lymphocytic thyroiditis and thyroid papillary carcinoma. A study of surgical cases among Japanese, and white and African Americans. Cancer 1995;76:2312-8. https://doi.org/10.1002/10970142(19951201)76:11<2312::aid-cncr2820761120>3.0.co;2-h

19 Medenica S, Radojevic N, Stojkovic M, et al. Autoimmunity and thyrotropin level in developing thyroid malignancy. Eur Rev Med Pharmacol Sci 2015;19:2824-9.

20 Boelaert K, Horacek J, Holder RL, et al. Serum thyrotropin concentration as a novel predictor of malignancy in thyroid nodules investigated by fine-needle aspiration. J Clin Endo Metab 2006;91:4295-301. https://doi.org/10.1210/jc.2006-0527

21 Jin J, Machekano R, McHenry CR. The utility of preoperative serum thyroid-stimulating hormone level for predicting malignant nodular thyroid disease. Am J Surg 2010;199:294-7. https://doi.org/10.1016/j. amjsurg.2009.08.028

22 Grebe SK. Thyroglobulin autoantibodies, thyroid nodules, and new insights into some old questions. Thyroid 2010;20:841-2. https://doi. org/10.1089/thy.2010.1651

23 Feldt-Rasmussen U, Rasmussen AK. Autoimmunity in differentiated thyroid cancer: significance and related clinical problems. Hormones 2010;9:109-17. https://doi.org/10.14310/horm.2002.1261

24 Spencer C, Fatemi S. Thyroglobulin antibody (TgAb) methods Strengths, pitfalls and clinical utility for monitoring TgAb-positive patients with differentiated thyroid cancer. Best Pract Res Clin Endocrinol Metab 2013;27:701-12. https://doi.org/10.1016/j. beem.2013.07.003

25 Hosseini S, Payne RJ, Zawawi F, et al. Can preoperative thyroglobulin antibody levels be used as a marker for well differentiated thyroid cancer? J Otolaryngol Head Neck Surg 2016;45:31. https://doi. org/10.1186/s40463-016-0143-5 